ining the distribution of hydrogen in the galaxy. The significance of the observations and the deductions which may be drawn from them are briefly discussed; and the report concludes with a list of the scientific institutions engaged in research on the 21-cm. line.

All three reports contain a comprehensive, but selected, list of references to the specific portions of the field of radio astronomy to which they refer. The fact that they were prepared by small groups of international workers makes them invaluable to all who are studying or pursuing research in this subject.

R. L. Smith-Rose

\section{BIOLOGY AND HUMAN AFFAIRS}

CHANGES in educational thought and practice 1 are usually so slight that they are scarcely discernible from one year to another; as time goes on they may build up into something formidable. Twenty years ago, for example, the teaching of biology in British schools was on a small scale. In many girls' schools botany was thought to be the only suitable biological subject, while in boys' schools botany was thought to be a subject suitable for girls, and little, except a smattering of 'nature study', was taught.

In 1935 the British Social Hygiene Council (now the British Social Biology Council), a voluntary organization formed originally to combat the venereal diseases, took the long view and turned to the educational service as a means of giving children rational information about the workings of their own bodies. It was expecting that actions based on this knowledge would lead to higher standards of health, and was hoping that a deeper insight into biology would endow men and women with a clearer appreciation of themselves as human beings; when associated with the understanding provided by the other life sciences, this would form the basis for better moral behaviour, particularly in relation to sex. The Council decided that its long-term objectives would best be achieved by promoting and supporting the development of biology teaching in schools. Public meetings were organized, as well as conferences, courses for teachers and summer schools. A journal, then called Biology, was launched, and now, under the name of Biology and Human Affairs, is celebrating twenty years of uninterrupted pub. lication.

During those twenty years changes in three different directions have been accompanied by corresponding changes in the nature of the journal itself. First, there has been a remarkable increase in the amount of biology teaching in schools. To-day the subject is taught in many grammar schools, and it is becoming firmly established in secondary modern and primary schools, although in some of these there is a tendency to offer it only to boys, while girls are busy with domestic science. Secondly, there has been a marked improvement in the content of the subjectmatter. It is developing into a genuine natural science, having depth as well as breadth; botany has been largely displaced by biology, a unified subject drawing its material and principles from both plants and animals.

The third direction in which progress has been marked is in the field of sex education. From its inception in 1914 until it ceased to be a semi-official body in 1942, the British Social Hygiene Council's main function was to act as a central organization for public enlightenment in relation to venereal disease. It was with this object in mind that the Council embarked on a vigorous campaign in favour of sex-education. At first it met with bitter opposition, particularly from religious bodies and official organizations, and sometimes from the schools, while those most favourably disposed towards this new development but who were least able to make their views effective were the children themselves. Bit by bit, however, the opposition was won over, and when in 1943 the Ministry of Education issued its pamphlet on "Sex-Education in Schools and Youth Organizations" the campaign might be said to have achieved its object. It would, of course, be presumptuous for the founders of Biology to claim credit for all these advances; they deserve their proportionate share.

To-day, Biology and Human Affairs appears as the journal of an organization, the British Social Biology Council, which is committed to promote and encourage the teaching of human biology as a cultural and practical subject; to preserve and strengthen the family as the basic social unit; and to encourage the dissemination of biological knowledge as a means of emphasizing the social responsibilities of individuals, the implications of population problems, the removal of conditions conducing to promiscuity, the elimination of commercialized vice, and a reduction in the incidence of social diseases, particularly the venereal diseases. The contents of its anniversary number indicate the broad catholic way in which those responsible for the production of the journal are seeking to implement the aims of its parent body. Articles include one on the adaptation of farm animals to their environment, by Dr. John Hammond; the fauna of built-up areas, by Dr. E. J. Popham; the natural history of the 'spiv', by Dr. P. D. Scott; the breeding behaviour of toads; a progress report on poliomyelitis; and the adventures and vicissitudes of a laboratory technician, by F. C. Taylor, senior laboratory steward at Eton College.

\section{HOSPITAL IN-PATIENT STATISTICS IN ENGLAND AND WALES}

$A^{\mathrm{s}}$ $S$ part of the Registrar General's statistical review of England and Wales for the two years 1950-51, a "Supplement on Hospital In-Patient Statistics" has been published* which makes available a fresh selection of material from a hospital in-patient inquiry started in 1949. The chief purposes of the inquiry were to assist hospital administrators by a more detailed analysis of the diseases treated and the types of patients involved; and also to increase the information available about the general pattern of ill-health in the community obtainable from mortality and morbidity data. Since the inquiry has, up to the present, been largely experimental, it has covered only a proportion of hospitals ; and, moreover, different selections of tables arc presented for the several years analysed. Sufficient experience has now been gained to put the project on a more permanent and comprehensive basis.

* The Registrar General's Statistical Review of England and Wales for the two years 1950-51: Supplement on Hospital In-Patient Statistics. Pp. iv +151. (London: H.M.S.O., 1955.) 78. 6d. net. 